\title{
HISTOPATHOLOGY STUDIES OF SELECTED ORGANS OF Hemichromis fasciatus INHABITING IGUN GOLD MINING AND OPA RESERVOIRS, OSUN STATE, NIGERIA: A COMPARATIVE STUDY
}

\author{
${ }^{* 1}$ Obayemi, O. E. and ${ }^{2}$ Komolafe, O. O.
}

\begin{abstract}
*IDepartment of Zoology, Obafemi Awolowo University, Ile-Ife, Osun State, Nigeria. Phone: +2347033568532 Email: obayemioluwadamilare@yahoo.com

${ }^{2}$ Department of Zoology, Obafemi Awolowo University, Ile-Ife, Osun State, Nigeria.

Phone: +2348033847764 Email: niyikomolafe2002@yahoo.co.uk
\end{abstract}

\begin{abstract}
This study examined the histopathological alterations in the gills, fillet and liver of Hemichromis fasciatus in Igun reservoir (located in an abandoned goldmine area) compared to those of Opa reservoir. Life fish species were collected from Opa and Igun reservoirs and identified in the laboratory. Techniques based on histological analyses were done on the organs and photomicrographs taken using digital binocular compound LED microscope. Epithelial lifting and hypertrophy of lamellae were observed in the gills of $H$. fasciatus in Opa reservoir and compared to rupture of gill epithelium, rupture of chloride cell, fusion, hyperplasia, curling of lamellae in $H$. fasciatus of Igun reservoir. The fillet of $H$. fasciatusin Opa and Igun reservoirs revealed splitting and atrophy of muscle bundles. Also, parasite cyst and necrosis were observed in the fillet of $H$. fasciatus of Igun reservoir compared to degeneration in muscle bundles in the fish of Opa reservoir. Similarly, the liver of $H$. fasciatus in Igun and Opa reservoirs showed splitting at the wall of central vein, hepatopancreas and liver cells degeneration. Moreover, nucleus hypertrophy was also identified in the liver of H. fasciatus in Opa reservoir compared to vascular congestion in the central vein, bile duct, portal vein and portal artery of $H$. fasciatus in Igun reservoir. The study therefore concluded that $H$. fasciatus specimens in Igun reservoir were histopathologically unhealthy as compared with those of Opa reservoir probably due to the high level of pollution resulting in bioaccumulation of heavy metals in Igun reservoir samples.
\end{abstract}

Keywords: gills, fillet, liver, Hemichromis fasciatus, histopathology, reservoir

LICENSE: This work by Open Journals Nigeria is licensed and published under the Creative Commons Attribution License 4.0 International License, which permits unrestricted use, distribution, and reproduction in any medium, provided this article is duly cited.

COPYRIGHT: The Author(s) completely retain the copyright of this published article.

OPEN ACCESS: The Author(s) approves that this article remains permanently online in the open access (OA) mode.

QA: This Article is published in line with "COPE (Committee on Publication Ethics) and PIE (Publication Integrity \& Ethics)". 


\section{INTRODUCTION}

The Cichlid, Hemichromis fasciatus (Peters 1857) commonly called banded jewel fish is an ornamental fish which occurs in various freshwater bodies in Africa. An increased pollution of the aquatic environment has caused severe alterations of tissues and organs in aquatic organisms (Mazonet al.,1999). The authors are of the view that in a disturbed environment, especially where pollutants occur in chronic and sublethal concentrations, changes in the structure and function of aquatic organisms are more frequent than mass mortality. Poleksic and MitrovicTutundzic (1994) noted that one of the possible methods of evaluating the effects of pollutants in fish is to examine their organs for morphological changes.

Raskovic (2010) reported that fish can be used to evaluate the health of aquatic ecosystems because contaminants build up in the food chain and are responsible for adverse effects and death in the aquatic systems. Also, studies carried out on various fishes have shown that heavy metals altered the physiological activities and biochemical parameters in organism tissues as observed by Popov et al. (2002), Golovanova (2008), Mary et al. (2015). The toxic effect of heavy metals in fish includes bioaccumulation, histopathological changes in tissues as reviewed by Usha Rani (2000); Adami, et al. (2002) andSehar et al. (2013)

Similarly, histopathological changes have been widely used as bio-indicators in evaluating the health of fish exposed to contaminants, both in the laboratory and field studies. Hence, histopathological alterations can be used as indicators for monitoring the effects of various anthropogenic pollutants on organisms and are a reflection of the overall health of the entire population in the ecosystem as reported by Mohammed (2009).Drishya et al. (2016) stated that one of the advantages of using histopathological bio-indicators in environmental monitoring is that this category of bio-indicators allows examining specific target tissues which includes: gills, kidney and liver that are responsible for vital roles. These functions are respiration, excretion and the accumulation and biotransformation of xenobiotics in the fish.

Furthermore, the alterations found in these organs are normally easier to identify than functional ones (Karthigayaniet al. 2014) and serve as warning signs of damage to animal health (Hinton and Laurén 1990). According to Yildizet al. (2010), increasing exposure to toxic elements in fresh water organisms such as fish and river birds which are often used to monitor the presence of contaminants can have adverse toxicological effects. Available records have shown that fish species in Igun reservoir bioaccumulated more heavy metals compared to fish species in Opa reservoir (Lawal and Komolafe 2012; Olabanji and Oluyemi, 2014).

This study therefore aims to compare histopathological alterations in the gills, fillet and liver of Igun and Opa reservoirs.

\section{MATERIALS AND METHODS STUDY AREA}

The study areas are abandoned gold mine reservoir at Igun village in Atakunmosa West Local Government area of Osun State and Opa freshwater reservoir at Ife central Local Government area of Osun State. The abandoned gold mine reservoir extends over longitude 004030E-004045E and latitude 07035N-07038N. Streams such as Oika, Eleripon and Osun which serve the community were impounded to form reservoirs in order to meet the mining needs of the Nigerian Mining cooperation which started in December 1941.

The second study area which is Opa reservoir is located in Ile-Ife, Osun State, Nigeria. Opa reservoir was impounded in 1978. The major tributaries are rivers Opa, Obudu and Esinmirin. The reservoir has a catchment 
area of about $116 \mathrm{~km}$. The reservoir extends over latitudes $07^{0} 21^{\prime} \mathrm{N}$ and $07^{0} 35^{\prime} \mathrm{N}$ and longitudes $004^{0} 311^{\prime} \mathrm{E}$ and $004^{0} 39^{\prime} \mathrm{E}$ (figure 1).

\section{COLLECTION OF FISH SAMPLES}

Fish samples were collected on a monthly basis using gill nets, cast net. They were identified using standard keys prepared by Paugy, et al. (2003) and Adesulu and Sydenham (2007). Samples of fish caught were put in a container filled with the reservoir water and dissected in situ.

\section{PREPARATION OF FISH TISSUES AND ORGANS FOR HISTOLOGICAL ANALYSIS}

Each fish specimen was split open anteriorly from the anal pore to the pectoral fin to remove its liver, while the gills were removed from the head region. A piece of fillet was also taken just above the lateral line and before the dorsal fin. Each fish gill, fillet and liver were put in a separate well labelled bottle, fixed in 5\% formalin for at least 48 hours and transferred into a sampling bottle rack. The method of Bernetet al. (1999) was used for tissues processing for histological studies, the tissues were removed from the fixative, and samples of tissue were rinsed in tap water for 5 minutes, dehydrated in ascending ethanol concentrations

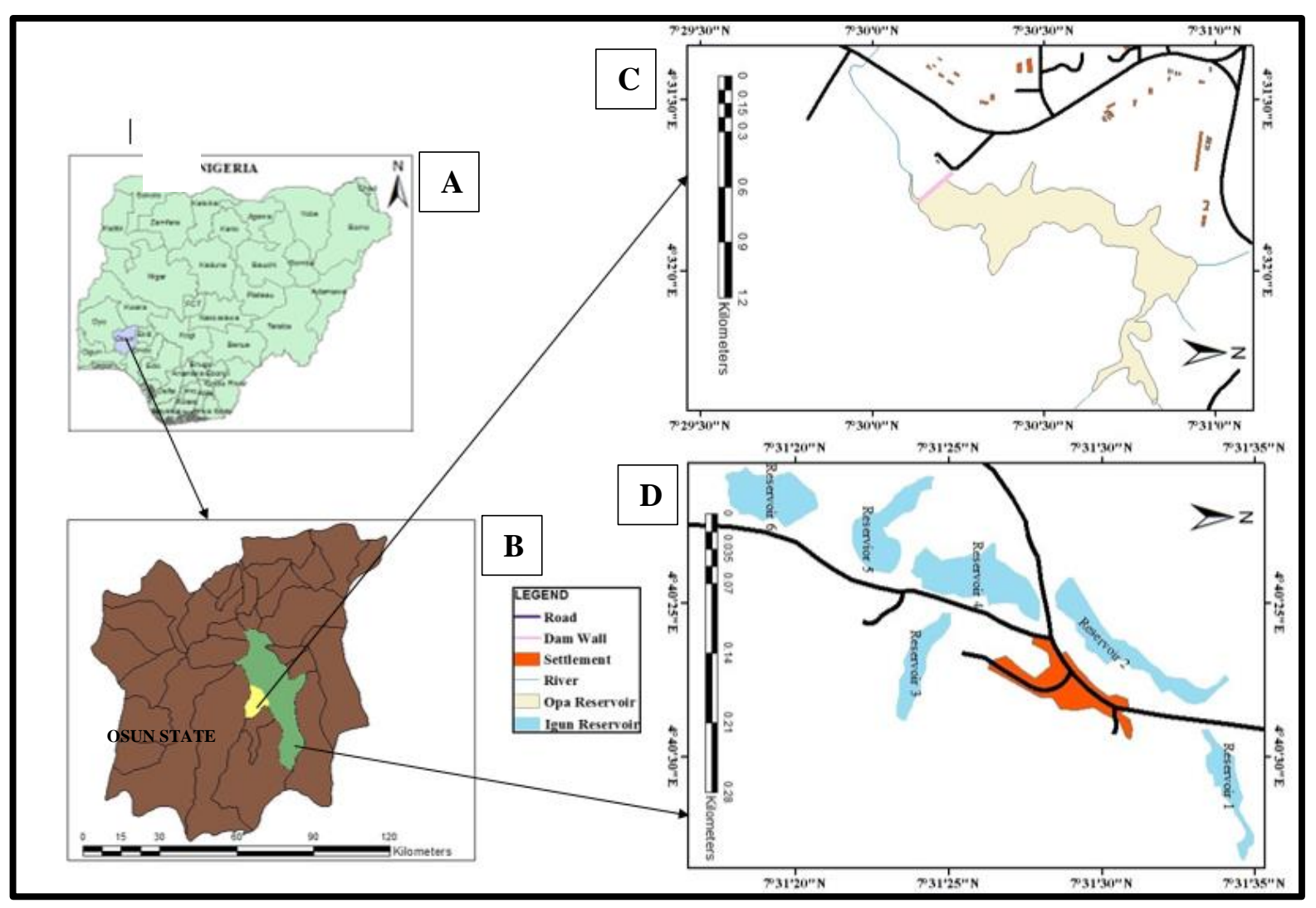

Figure 1: Map of Opa and Igun reservoirs showing its location in Nigeria $A=$ Nigeria, $B=$ Osun State, $C=$ Opa Reservoir, $D=$ Igun Reservoir 
(70\%, 80\% and 90\% alcohol) for minimum of 2 minutes, cleared or infiltrated in a wax miscible agent (xylene)for 2 minutes and then embedded in paraffin using standard protocols. The fish tissues were then cut into sections of approximately $5 \mu \mathrm{m}$ thickness from the block using a rotary microtome (Yamato Kohki, Serial no: 75010JO). The cut samples were dried in a hot air oven to remove moisture and each section were mounted on a glass slide. The sections were de-waxed in a wax-miscible agent, rehydrated through descending concentrations of ethanol $(90 \%, 80 \%$ and $70 \%$ alcohol) for at least 2 minutes. The sections were then stained with haematoxylin and eosin (Bancroft and Cook 1994), in which the tissues were place in haematoxylin solution for 3 minutes and aqueous eosin for 3 minutes, mounted on a slide and covered with coverslip and labelled appropriately. The tissues were examined, and microphotographs taken using a digital binocular compound LED microscope (model MD827S30L series).

\section{RESULTS}

\section{HISTOPATHOLOGICAL ALTERATIONS IN THE ORGANS OF Hemichromis fasciatusin OPA AND IGUN RESERVOIRS}

The gills of Hemichromis fasciatus in Opa reservoir showed normal primary and secondary lamellae. However, hypertrophy of primary lamellae was observed as shown in Plate 1.1a and epithelial lifting (Plate 1.1e). The photomicrograph of gill section in H. fasciatus of Igun reservoir showed fusion of secondary lamellae (Plate 1.1b), hyperplasia of secondary lamellae (Plate 1.1d), rupture of gill epithelium and curling of secondary lamellae (Plate $1.1 f)$.

The histopathological changes observed in the fillet of $H$. fasciatus of Opa reservoir includes atrophy of muscle bundles (Plate 1.2a); degeneration in muscle bundles in Plate 1.2c and splitting of muscle bundles (Plate 1.2e). The photomicrograph result of fillet section in H. fasciatus of Igun reservoir showed parasite cyst and atrophy of muscle bundles (Plate 1.2d); splitting of muscle bundles and splitting of muscle myofibrils (Plate 1.2f).

Result of the histopathological examination of $H$. fasciatus liver in Opa reservoir include splitting at the wall of central vein as shown in (Plate 1.3a); hepatopancreas degeneration and degeneration in liver cells (Plate 1.3c) and nucleus hypertrophy (Plate 1.3e). Histopathological alterations in the liver of $H$. fasciatusin Igun reservoir are shown in Plate 1.3b, with vascular congestions in central vein, splitting at the wall of central vein; vascular congestion in the portal vein, bile duct, and portal artery. Degeneration of liver cells and hepatopancreas degeneration was also observed (Plate 1.3d) as well as nucleus hypertrophy as shown in (Plate 1.3f).

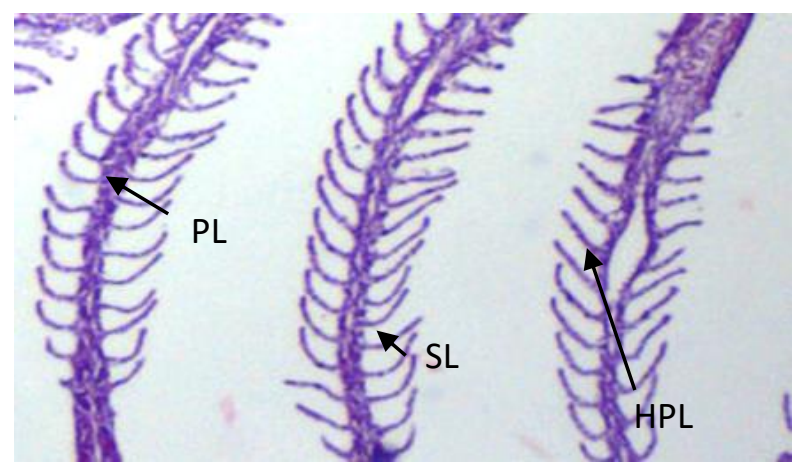

Plate 1.1a: Photomicrograph of gill section in Hemichromis fasciatus of Opa reservoir (Mag. X40)

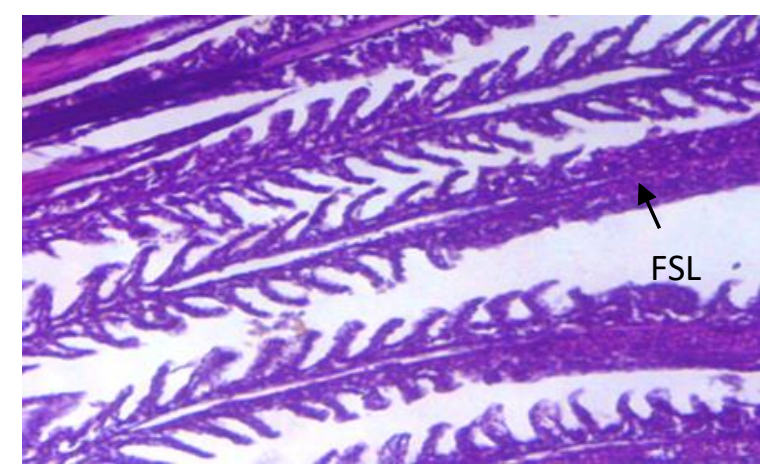

Plate 1.1b: Photomicrograph of gill section in $\mathrm{H}$. fasciatus of Igun reservoir (Mag. X40) 


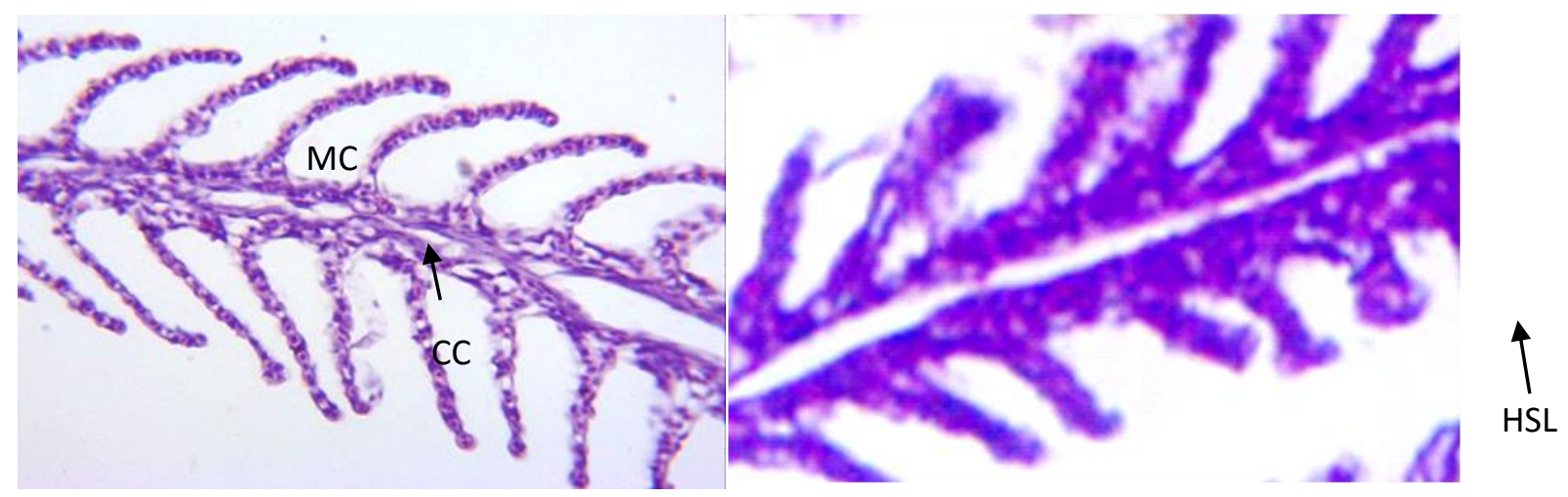

Plate 1.1c: Photomicrograph of gill section in H. fasciatus of Opa reservoir(Mag. X400)

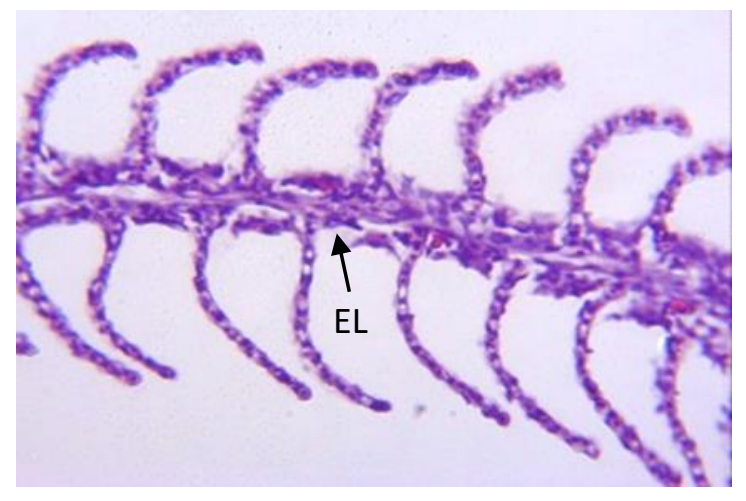

Plate 1.1e: Photomicrograph of gill section in H. fasciatus of Opa reservoir(Mag. X400)
Plate 1.1d: Photomicrograph of gill section in H. fasciatus of Igun reservoir(Mag. X400)

Keys:primary lamellae (PL), secondary lamellae (SL), hypertrophy of primary lamellae (HPL), fusion of secondary lamellae (FSL), mucous cell $(M C)$, chloride cell $(C C)$ hyperplasia of secondary lamellae (HSL), epithelial lifting $(E L)$, rupture of gill epithelium (RGE), curling of secondary lamellae (CSL) and rupture of chloride cells (RCC).

Haematoxylinand Eosin stain.

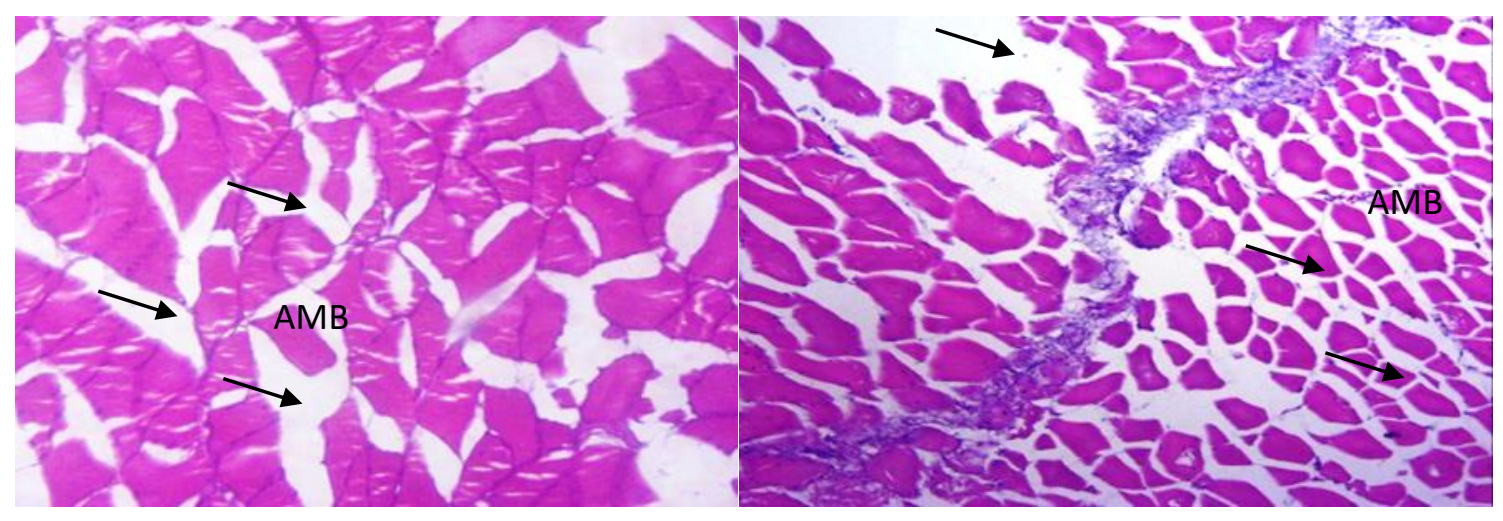

Plate 1.2a: Photomicrograph of fillet section in Hemichromis fasciatus of Opa reservoir (Mag. X40)

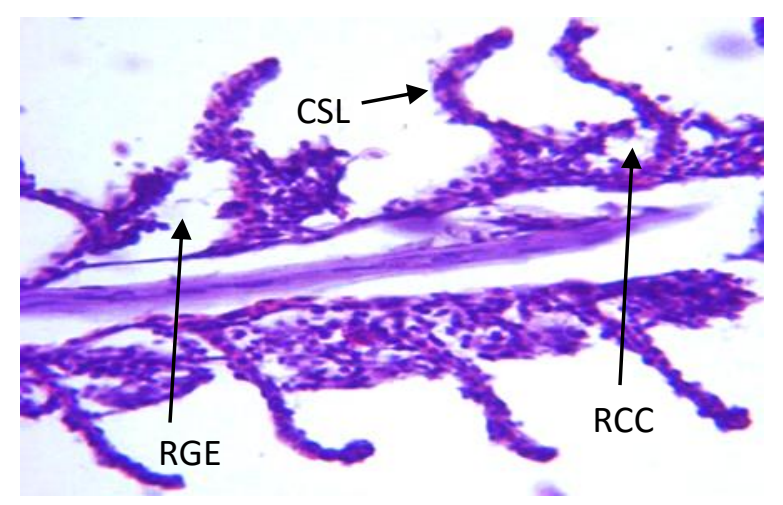

Plate 1.1f: Photomicrograph of gill section in H. fasciatus of Igun reservoir(Mag. X400) 


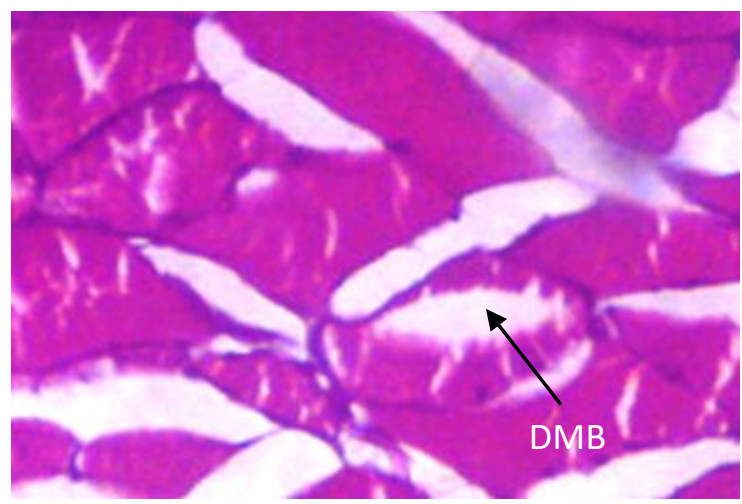

Plate 1.2c: Photomicrograph of fillet section

in H. fasciatus of Opa reservoir(Mag. X100)in

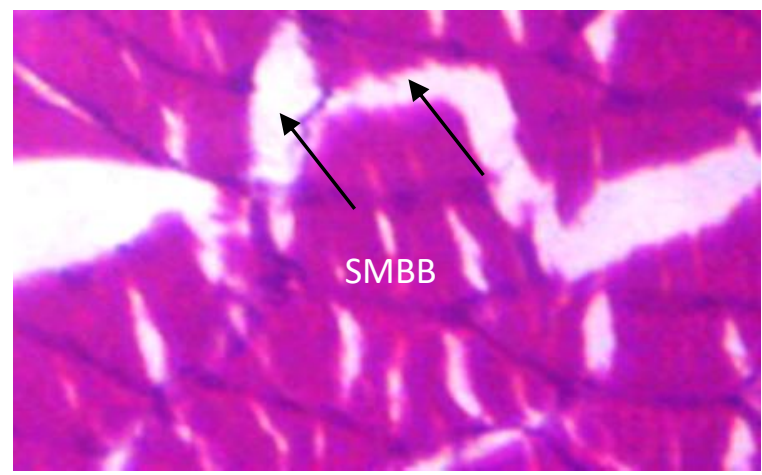

Plate 1.2e: Photomicrograph of fillet section

in $H$. fasciatus of Opa reservoir(Mag. X400)

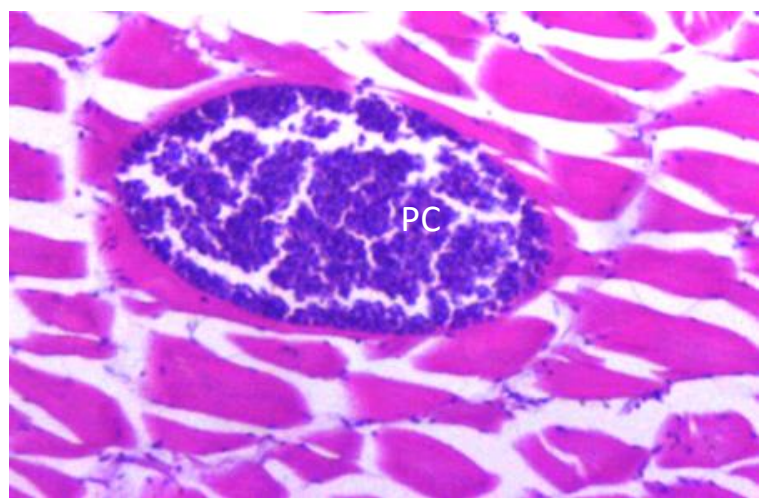

Plate 1.2d: Photomicrograph of filletsection

H. fasciatus of Igun reservoir(Mag. X100)

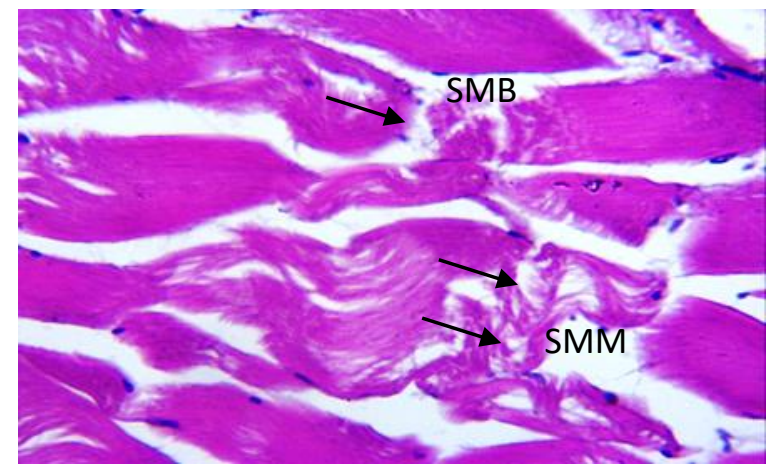

Plate 1.2f: Photomicrograph of filletsection

in $H$. fasciatus of Igun reservoir(Mag. X400)

Keys: atrophy of muscle bundles (AMB), degeneration in muscle bundles (DMB), parasite cyst (PC), splitting of muscle bundles (SMB), splitting of muscle myofibrils (SMM).

\section{Haematoxylinand Eosin stain.}

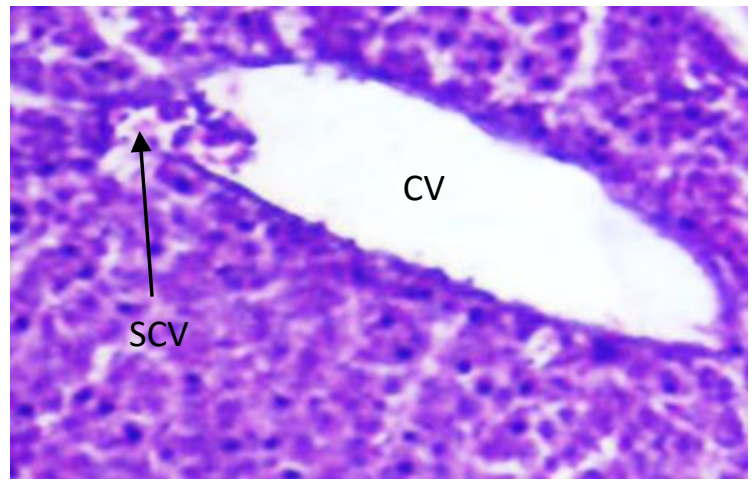

Plate 1.3a: Photomicrograph of liver section in Hemichromis fasciatus of Opa reservoir (Mag. X100)

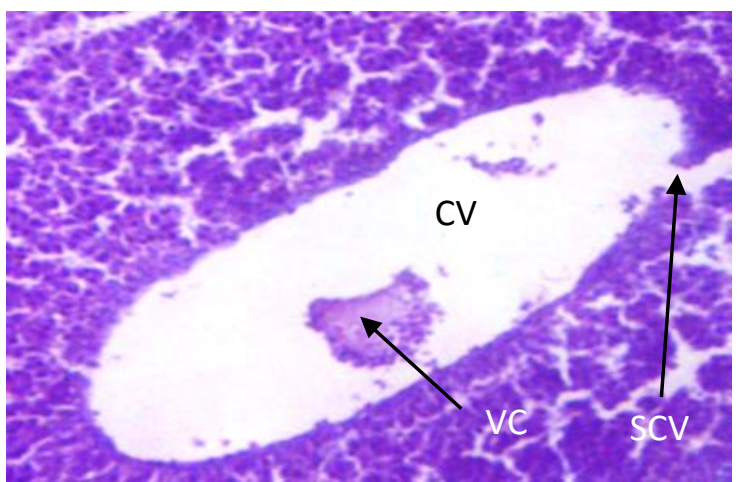

Plate 1.3b: Photomicrograph of liversection in H. fasciatus of Igun reservoir(Mag. X100) 


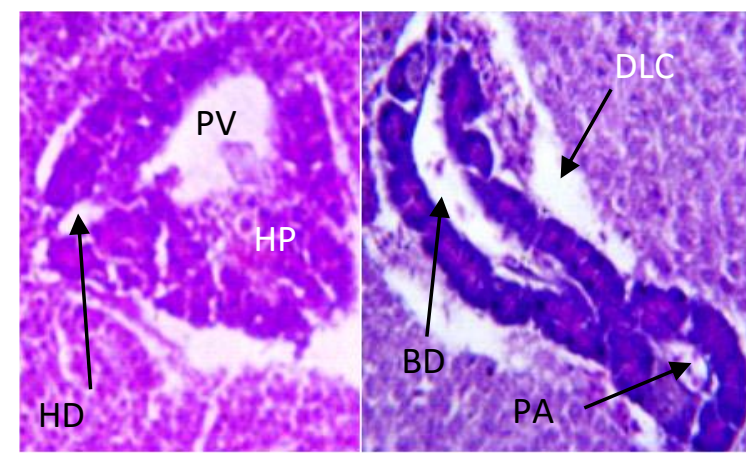

Plate 1.3c: Photomicrograph of liver section

in H. fasciatus of Opa reservoir(Mag. X100)

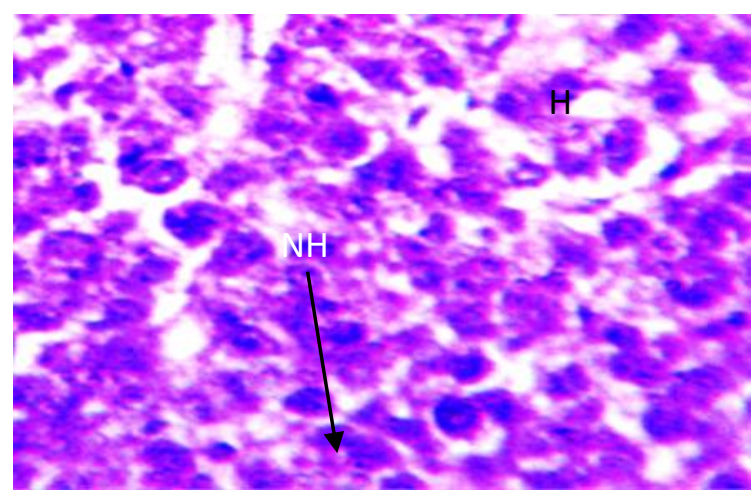

Plate1.3e: Photomicrograph of liver section

in H. fasciatus of Opa reservoir(Mag. X400)

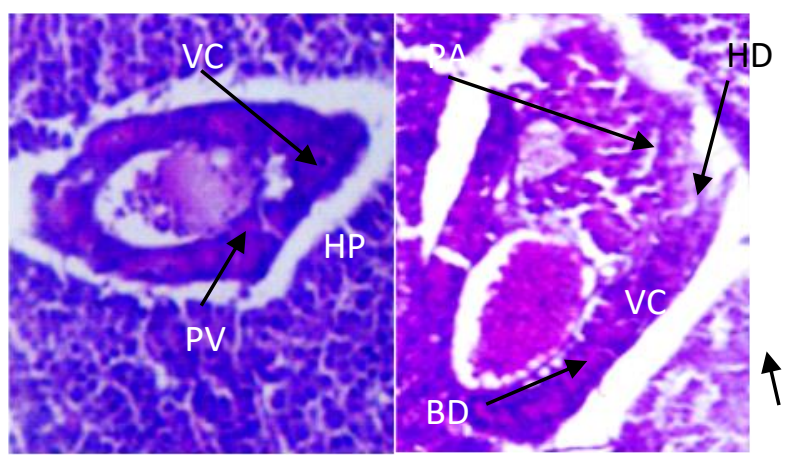

Plate 1.3d: Photomicrograph of liversection

in H. fasciatus of Igun reservoir(Mag. X100)

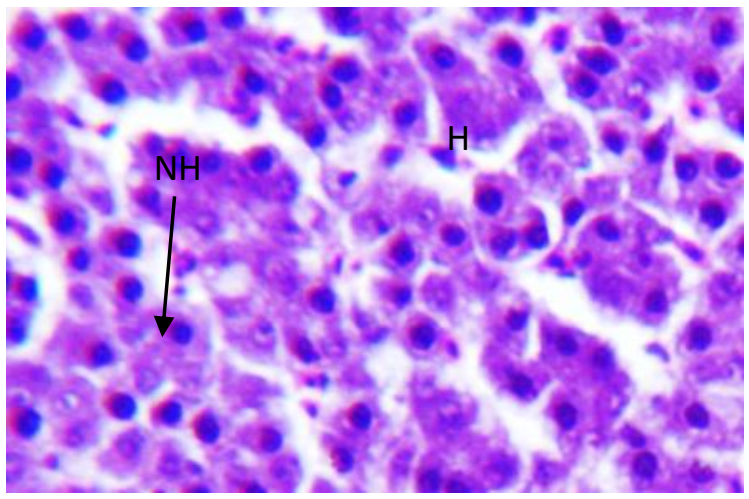

Plate 1.3f: Photomicrograph of liversection inH. fasciatus of Igun reservoir(Mag. X400)

Keys: splitting at the wall of the central vein (SCV), central vein (CV),vascular congestion (VC), portal vein (PV), hepatopancreas degeneration $(H D)$, hepatopancreas $(H P)$, bile duct (BD), degeneration of liver cells (DLC), portal artery $(P A)$, nucleus hepatocytes $(N H)$, hepatocyte $(H)$.

Table 1: Histopathological Alterations in the Organs of Hemichromis fasciatusin Opa Reservoir and Stages of Severity of the Alterations

\begin{tabular}{cll}
\hline Organs & Histopathological alterations & Stage \\
\hline Gills & Hypertrophy of primary filament & I \\
& Epithelial lifting & I \\
Fillet & Atrophy of muscle bundles & I \\
\hline & Splitting of muscle bundles, & I \\
& Degeneration in muscle bundles & II \\
\hline Liver & Splitting at the wall of the central vein & I \\
& Nucleus hepatocytes & I \\
& Hepatopancreas degeneration & II \\
& Degeneration of liver cells & II \\
\hline
\end{tabular}

Stage I = slight alteration, Stage II = moderatealteration, Stage III = severe alteration (Source: Simonato et al., 2008) 
Table 2:Histopathological Alterations in the Liver of Hemichromis fasciatusin Igun Reservoir and Stages of Severity of the Alterations

\begin{tabular}{llc}
\hline Organs & Histopathological alterations & Stage \\
\hline Gills & Fusion of secondary lamellae & I \\
& Hyperplasia of secondary lamella & I \\
& Curling of secondary lamellae & II \\
& Rupture of gill epithelium & II \\
& Rupture of chloride cells & II \\
\hline Fillet & Atrophy of muscle bundles & I \\
& Splitting of muscle myofibrils & I \\
& Splitting of muscle bundles & I \\
& Parasite cyst & I \\
\hline Liver & Splitting at the wall of the central vein & I \\
& Nucleus hypertrophy & I \\
& Hepatopancreas degeneration & II \\
& Central vein with vascular congestions & II \\
& Portal vein with vascular congestion & II \\
& Portal artery with vascular congestion & II \\
& Vascular congestion in the bile duct & II \\
& Degeneration of liver cells & II \\
\hline
\end{tabular}

Stage I = slight alteration, Stage II = moderatealteration, Stage III = severe alteration

(Source: Simonato et al., 2008)

\section{DISCUSSION}

The gills of a fish play a vital role in maintaining of aquatic organism ionic homeostasis (Evans, 1993). Subsequently many contaminants come in close contact with gill epithelium and causes injury. The damages could depend on the level and period of exposure of the pollutants. Hypertrophy of primary lamellae and epithelial lifting observed in the gills of $H$. fasciatus in Opa reservoir were similar to the results of Yogitaand Mishra (2013). The authors noted that epithelial lifting could lead to dysfunctional or even non-functional gills, and sudden death of the fish. Similarly, histopathological alterations observed in the gills of $H$. fasciatus in Igun reservoir were similar to the findings of Abdullah (2001) who observed epithelial necrosis and rupture of the gill epithelium induced by zinc ions in Cyprinus carpio. The epithelium lifting is considered to be one of the initial reactions of the gill to variety of pollutants according to Al-Mansoori (2006). The histopathological alterations in this organ are a response to exposure to non-specific pollutants (Au, 2004).

Also, atrophy and splitting of muscle bundles revealed in the fillet of H. fasciatus in Opa and Igun reservoirs was likewise recorded by Ramesh and Nagarajan (2013) in the muscle of Clarias batrachus. The degeneration of muscle bundles seen in the fillet of $H$. fasciatus in Opa reservoir was also reported by Kaoud and El-Dahshan (2010) in the muscle of $O$. niloticus. It can thus be suggested that different alterations observed in the fillet of $H$. fasciatus in Opa and Igun reservoirs could be due to the presence of various contaminants in the reservoir.

Histopathological alterations observed in the liver of $H$. fasciatusin both reservoirs were similarly recorded by Chavan and Muley (2014) in the liver of Cirrhinus mrigala. These lesions are hepatopancreas degeneration, 
splitting at the wall of central vein, degeneration of liver cells and nucleus hypertrophy. It seems possible that these alterations are due to heavy metals pollution in the two reservoirs. Furthermore, hepatopancreas degeneration observed in the liver of $H$. fasciatus in Opa reservoir was similar to the report of Naeemi et al. (2013) on histopathological changes of gills, kidney and liver of Caspian kutumexposed to Alkylbenzene Sulfonate. Also, vascular congestion in central vein, portal vein and bile duct seen in the liver of $H$. fasciatus of Igun reservoir were similar to the alterations observed in the liver of Anabas testudineusin Ban Pu Reservoir according to Saenphetet al. (2009). A possible explanation for congestion in the liver cells could be as a result of injury to the cells. The results of this study is in agreement with the work of Osman et al. (2009) who reported congestion in liver cells of Oreochromis niloticus exposed to polluted water. This study has shown that the organs of $H$. fasciatus in Igun reservoir was severely damaged compared to the organs of $H$. fasciatus in Opa reservoir. The findings of this study suggest that aquatic pollution resulting from mining activities in Igun reservoir may have resulted to severe changes recorded in the organs of $H$. fasciatus in Igun reservoir.

\section{CONCLUSION}

The results of this study have shown that more alterations were found in the tissues of $H$. fasciatus in Igun reservoir compared to Opa reservoir. The evidence from this study suggests that bioaccumulation of heavy metals in the tissues of fish from Igun reservoir could have resulted in severe changes in the tissue. 


\section{REFERENCES}

Abdullah, A. (2001). Histological changes induced by zinc ion in the gills of common carp Cyprinus carpio (L.) juveniles. Journal of Agricultural Science, 14(2): 19-25.

Adami, G.M., Barbieri, P., Fabiani M., Piselli S., Predonzani S. and Reisenhofer, E. (2002). Levels of cadmium and zinc in hepatopancreas of reared Mytilus galloprovincialis from the Gulf of Trieste (Italy). Chemosphere,48(7): 671-677.

Adesulu, E.A. and Sydenham, D.H.J. (2007). The freshwater fishes and fisheries of Nigeria, Macmillan Nigeria Publishers Limited, Ibadan. 397pp.

Al-Mansoori, A.F. (2006). Histological changes induced by cadmium ion in the Gills, Liver and Intestine of juvenile Carassius carassius (L.) Basrah Journal of Science, 24(1): 32-46.

Au, D.W. (2004): The application of histo-cytopathologicalbiomarkers in marine pollution monitoring: a review. Marine Pollution Bulletin, 48(9-10):817-34.

Bancroft, J.D. and Cook, H.C. (1994). Manual of histological techniques and their diagnostic application, Churchill Livingstone, London. pp. 289-305

Bhatkar, N., Vankhede, G.N., and Dhande, R.R. (2004): HeavyMetal Induced Biochemical Alterations in the FreshWater Fish Labeo rohita, Journal of Ecotoxicology and Environmental Monitoring., 1(14), 1-7.

Chavan, V.R. and Muley, D.V. (2014). Effect of heavy metals on liver and gill of fish Cirrhinus mrigala. International Journal of Current Microbiology and Applied Sciences,3(5): 277-288.

Drishya, M.K., Binu, K.S., Mohan, K.M., Ambikadevi, A.P. andAswin, B. (2016): Histopathological changes in the gills of fresh waterfish, Catla catla exposed to electroplating effluent

Evans, D.H. (1993): Osmotic and ionic regulation, In: The physiology of fishes, edited by D.H. Evans, Boca Raton,

FL: CRC, 315-341.

Golovanova, I. L. (2008): Effects of Heavy Metals on the Physiological and Biochemical Status of Fishes and Aquatic Invertebrates, Inland Water Biology,1(1): 93-101. doi: 10.1134/S1995082908010148

Hinton, D.E. and Lauren, D.J. (1990). Liver structural alterations accompanying chronic toxicity in fishes: potential biomarkers of exposure. In: Biomarkers of Environmental Contaminations (edited by J.F. McCarthy and L.R. Shugart), pp. 17-57. Lewis Publisher, Boca Raton, FL.

Kaoud, H.A. and El-Dahshan, A.R. (2010). Bioaccumulation and histopathological alterations of the heavy metals in Oreochromis niloticus fish,.Nature and Science,8(4), 147-156.

Karthigayani, T., Denis, M., Remy, A.R.A. and Shettu, N. (2014): Histological study of the intestine and liver tissues in the fish Oreochromismossambicus exposed to cypermethrin.Journal of Modern Biotechnology,3(4) $48-54$.

Komolafe, O.O. and Lawal, O.A. (2012). Concentrations of Heavy Metals in Three Tilapine Species of an Abandoned Gold Mine Resevoir in Igun, Nigeria. Nigerian Journal of Fisheries, 9(2), 581- 585.

Mary, S.C.H., Bhuvaneswari, D.and Anandan, R. (2015): Biochemical and histopathological studies on lead nitrate induced toxicity infresh water fish grass carp (Ctenopharyngodon Idella). European Journal of Experimental Biology, 5(11):24-30 
Mazon, A.F., Cerqueira, C.C.C., Monteiro, E.A.S. and Fernandes, M.N. (1999). Acute copper exposure in freshwater fish: Morphological and physiological effect. In VAL, AL. and ALMEIDA-VAL, VMF. Biology of tropical fishes. Manaus: INPA. 263-275.

Mohamed, F.A.S. (2009). Histopathological Studies on Tilapia zillii and Solea vulgaris from Lake Qarun, Egypt. World Journal of Fish and Marine Sciences, 1(1), 29-39.

Naeemi, A., Jamili, S., Shabanipour, N., Mashinchian, A. and Shariati Feizabadi, S. (2013). Histopathological changes of gill, liver and kidney in Caspian kutum exposed to Linear Alkylbenzene Sulfonate. Iranian Journal of Fisheries Sciences,12(4), 887-897.

Olabanji, I.O. and Oluyemi, E.A. (2014). Preliminary assessment of heavy metal pollution of Opa reservoir, Ile-Ife, South west, Nigeria using Mormyrus rume and Tilapia zillii. Ife Journal of Science,16(1), 35-43.

Osman, M. M., EL-Fiky, S. A., Soheir, Y. M .and Abeer, A. I. (2009). Impact of Water pollution on Histopathological and Eletrophoretic Characters of Auriochromis niloticus Fish. Research Journal of Environmental Toxicology. 3(1): 9-23.

Paugy, D., Leveque, C. and Teugel, G.G. (2003). The Fresh and Brackish Water Fishes of West Africa. Vols. I and II. IRD Editions. 455pp and 815pp. Publications Scientiques du Museum.

Poleksic, V. and Mitrovic-Tutundzic, V. (1994). Fish gills as a monitor of sublethal and chronic effects of pollution. In: Müller, R. and Lloyd, R., Ed. Sublethal and chronic effects of pollutants on freshwater fish. pp. 339 352. Cambridge: Cambridge University Press.

Popov, P.A., Androsova, N.V., and Anoshin, G.N. (2002): Accumulation and Distribution of Heavy and Transient Metals in the Novosibirsk Reservoir Fish, Voprosy Ikhtyologii, 2(42), 264-270.

Ramesh,M. andNagarajan, K. (2013). Histopathological Changes in the Muscle Tissue of the Fish Clarias batrachus exposed to Untreated and Treated Sago Effluent. Advances in Bioscience and Bioengineering, 1(2), 74-80.

Raskovic, B. Poleksic, V., Zivic, I. and Spasic, M. (2010): Histology of carp (Cyprinus carpio, 1.) Gills and pondWater quality in semi intensive production, Bulgarian Journal of Agricultural Science, 16(3), 253-262

Saenphet, S., Thaworn, W. and Saenphet, K. (2009). Histopathological alterations of the gills, liver and kidneys in Anabas testudineus (BLOCH) fish living in an unused lignite mine, Li District, Lamphun Province, Thailand. Journal of Tropical Medicine and Public Health,40(5), 1121-1126.

Sehar, A.S., Ali, S., Uzma, S.A., Mujahid, F., Saima, A.B., Hannan, R.A. (2014) Effect of Different Heavy Metal Pollution on Fish, Research Journal of Chemical and Environmental Sciences, 2(1): 74-79.

Trivedi, R.K. and Goel, P.K. (1984). Chemical and biological methods for water pollution studies. pp 1-251. Environmental Publications, Karad.

Usha Rani, A. (2000). Cadmium induced bioaccumulation in tissue of freshwater teleost Oreochromis mossambicus. Annals of the New York Academy of Science 919, 318-320.

Yildiz, D., Kula, I., Ay, G., Baslar, S. and Dogan, Y. (2010). Determination of Trace Elements in the Plants of Mt. Bozdag, Izmir, Turkey. Archive of Biological Science,62(3), 731-738. 
Yogita, D. and Mishra, A. (2013). Histopathological Alterations in Gill and Liver Anatomy of freshwater, Air Breathing Fish Channa Punctatus after Pesticide Hilban (Chlorpyrifos) Treatment. Advanced Bioresearch,4(2), 57-62.

\section{APPENDIX}

\section{Reagents}

1. $5 \%$ formalin

2. Xylene

3. $90 \%$ alcohol

4. $80 \%$ alcohol

5. $70 \%$ alcohol

6. Haematoxylin solution

7. Aqueous eosin 